\title{
Reproduction and adaptation characteristics in D'man sheep
}

\author{
A. LAHLOU-KASSI, S. BENLAMLIH, R. BOUKLIQ, A. TIBARY and \\ I. BOUJENANE
}

Hassan II Agronomic and Veterinary Medicine Institute, P.O. Box 6202, Rabat-Instituts, Morocco

\begin{abstract}
D'man breed (D) is found in the oasis of the subsaharian regions of Morocco and reared usually in sedentary type of management with small flocks ( $<10$ ewes). Preliminary field surveys showed that D is early maturing, prolific and aseasonal. Hence, a multidisciplinary research programme on D was started in 1974.

This paper reports the findings of these studies and describes the approach used to (1) characterize and evaluate the performances of D in field and station, (2) study the physiological mechanism involved in its peculiar reproduction and production, (3) study the genetic basis of reproduction parameters, and (4) evaluate use of D in crossbreeding schemes to improve the productivity of other Moroccoan breeds.

Results show that $\mathrm{D}$ is one of the rare breeds that is simultaneously early maturing, highly prolific and completely aseasonal. However, studies on water turnover and nitrogen recycling show that $\mathrm{D}$ is not well adapted to hot climate and poor nutrition.

Its reproduction parameters are relatively independent of photoperiod and related to a low sensitivity to negative oestrogen feedback. D male is characterized by high libido and can be used for synchronizing oestruses through the wram effect's.

Crossbreeding experiments with non-prolific sheep confirm the heritability of reproductive parameters. However, the genetic basis for these is not yet well known.
\end{abstract}

Index words: D'man, reproduction, adaptation, crossbreeding, early maturity, libido

\section{Introduction}

Early work undertaken on D'man (D) breed both in station and on the field showed reproductive characteristics of this breed which are different from those of other Moroccan breeds: precocious puberty
(219-229 d), a short postpartum anestrus (34-64 d), non seasonality of breeding and high prolificacy $(2.86)(7,17,19,20)$. With an ovulation rate (OR) of 2.85 (17), D ewe is considered among the most prolific breeds as this OR approaches that of other prolific breeds (Romanov 2.86, Boorola 2.68, Finn- 
sheep 3.31) (30) and is higher than that of other Moroccan breeds (Beni-Hsen 1.25, Timahdite (T) 1.1, Beni-Guil 1.1, Sardi (S) 1.1). Prolificacy in D varies from 2 to 2.6 compared to that of Beni-Hsen (1.18), T (1.0), S (1.0) and Beni-Guil (1.0) $(4,8,17)$.

Experiments were designed to try to determine the physiologic mechanism and genetic components which are behind these characteristics; these esperiments can be summarized as follows:

- Studies of litter size (LS), OR and embryo survival (ES).

- Determination of endocrine regulation of multiovulation.

- Determination of photoperiod and genetic involvement in the expression of sexual activity.

- Studies on adaptation of D to harsh environment and its possible use for intensification of sheep production through crossbreeding with local meat breed like Sardi.

\section{Litter size and its components}

\subsection{Litter size}

From the analysis of 1852 performances gathered in two stations at Ziz valley, BouJENANE et al. (6) reported an average LS of 2.09 , ranging from 1.77 in ewes of less than 12 months old to 2.32 in ewes for which age was between 30 and 42 months (Table 1). Moreover, LS varied from 1 to 3 in ewe lambs and from 1 to 7 in ewes older than 42 months.

In a crossbreeding experiment involving D and $\mathrm{S}$ purebreeds, Boujenane et al. (6) reported that the average LS were $1.80,1.20$ and 1.55 in $\mathrm{D}, \mathrm{S}$ and $\mathrm{D} \times \mathrm{S}$ ewes. These results which are in agreement with those of BRADFORD al. (9) (Table 2) shows that LS varied from 1 to 6 in D, 1 to 3 in S and 1 to 4 in $\mathrm{D} \times \mathrm{S}$ ewes. It seems from these that LS has an additive inheritance, since heterosis was small $(1.4 \%)$. This result agrees with several other studies $(10,22,28)$.

\subsection{Ovulation rate}

From Table 3, OR in adult D ewes (3.18) is signifantly higher than in 1-year old ewe lambs (1.9 to 2.3). It ranged from 1 to 7 and from 1 to 4 for adult and young females, respectively. The mode of the OR distribution is 3 and 2 for both groups. Seasonal variation of OR is not significant.

Repeatability of OR as determined through simple correlation of OR on 2 successives cycles in $15 \mathrm{D}$ ewes was 0.59 (20). However, it ranged only from 0.2 to 0.37 when calculated, through simple correlation between pairs of data for 3 seasons (9).

In comparing $\mathrm{OR}$ of $\mathrm{D}, \mathrm{S}$ and their crossbred ewes, BouJENANE et al. (5) found averages of $2.56,1.23$ and 1.92 respectively. Moreover, OR ranged from 1 to 8,1 to 3 , and 1 to 4 in D, S and D $\times \mathrm{S}$ ewes (Table 4). It is essential to point out that as the mean OR increases, the proportion of single births decreases while that of multiple births increases.

High repeatability of OR in this breed indicates the possibility of presence of a major gene comparable to the Boorola gene reported by PIPER and BINDON (26). On the other hand, individual heterosis for OR was small and negative $(-0.5 \%)(6)$. This result shows that OR is controlled by additive genes and it is in agreement with those of Land et al. (22) and RiCORDEAU et al. (28).

\subsection{Embryo survival}

ES reported in D (Table 5) is as high as that of Romanov (28) and Javanese (12). This trait is influenced by age. OR and LS were respectively $(2.89,2.07)$ and $(2.27,1.35)$ for adult ewes and ewes lambs giving an ES rate of 0.72 and 0.59 for these age groups. This suggest that LS is more correlated to OR in adult ewes than in ewelambs.

In addition, averages of ES were $68.3 \%$, $83.7 \%$ and $95.4 \%$ in D, D $\times \mathrm{S}$ and $\mathrm{S}$ ewes which ovulated respectively. The effect of breed group for the same number of corpora 
lutea was not significant $(\mathrm{P}>.05)$. The only pora lutea were 1, 2, 3 and 4 or greater, ES effect on embryo mortality was the number was $81.2 \%, 86.8 \%, 79.2 \%$ and $66.3 \%$ of ova shed. Thus, when the number of correspectively. An equation similar to that of

Table 1. Least squares means and distribution of litter size in D'man ewes by age class.

\begin{tabular}{|c|c|c|c|c|c|c|c|c|c|c|}
\hline \multirow{2}{*}{$\begin{array}{l}\text { Age } \\
\text { class } \\
\text { (months). }\end{array}$} & \multirow{2}{*}{$\begin{array}{c}\text { Number } \\
\text { of } \\
\text { obs. }\end{array}$} & \multirow{2}{*}{$\begin{array}{l}\text { Least } \\
\text { squares } \\
\text { means }\end{array}$} & \multirow{2}{*}{$\begin{array}{l}\text { Stan- } \\
\text { dard } \\
\text { error }\end{array}$} & \multicolumn{7}{|c|}{ Frequency $(\%)$} \\
\hline & & & & 1 & 2 & 3 & 4 & 5 & 6 & 7 \\
\hline$<12$ & 48 & 1.77 & .13 & 43.8 & 45.8 & 10.4 & - & - & - & - \\
\hline 12 to 18 & 395 & 2.02 & .05 & 30.4 & 47.8 & 18.7 & 2.8 & .3 & - & - \\
\hline 18 to 24 & 267 & 2.12 & .06 & 28.1 & 42.3 & 23.6 & 4.9 & .7 & .4 & - \\
\hline 24 to 30 & 292 & 2.21 & .05 & 22.6 & 44.5 & 26.7 & 4.5 & 1.7 & - & - \\
\hline 30 to 42 & 356 & 2.32 & .05 & 18.0 & 44.6 & 27.0 & 9.0 & 1.1 & .3 & - \\
\hline$>42$ & 494 & 2.13 & .05 & 28.9 & 39.5 & 24.3 & 6.3 & .6 & .2 & .2 \\
\hline All ages & 1852 & 2.09 & .03 & 26.4 & 43.6 & 23.5 & 5.4 & .8 & .2 & .1 \\
\hline
\end{tabular}

Table 2. Variability in litter size of Sardi, D'man and F1 ewes. (9).

\begin{tabular}{|c|c|c|c|c|c|c|c|c|c|}
\hline \multirow[t]{2}{*}{ Breed } & \multirow{2}{*}{$\begin{array}{l}\text { Age at } \\
\text { mating }\end{array}$} & \multirow{2}{*}{$\begin{array}{l}\text { Total no. } \\
\text { litters }\end{array}$} & \multirow{2}{*}{$\begin{array}{l}\text { Mean litter } \\
\text { size }\end{array}$} & \multicolumn{6}{|c|}{ Frequency $(\%)$} \\
\hline & & & & 1 & 2 & 3 & 4 & 5 & 6 \\
\hline \multirow[t]{2}{*}{ Sardi } & $20 \mathrm{mo}$ & 136 & 1.11 & 73.8 & 9.6 & - & - & - & - \\
\hline & $10 \mathrm{mo}$ & 20 & 1.00 & 100 & - & - & - & - & - \\
\hline \multirow[t]{2}{*}{ D'man } & $20 \mathrm{mo}$ & 12 & 2.17 & 41.7 & 16.7 & 33.3 & - & 8.3 & - \\
\hline & $10 \mathrm{mo}$ & 33 & 1.58 & 42.4 & 51.5 & 6.1 & - & - & - \\
\hline \multirow[t]{2}{*}{$\mathrm{D} \times \mathrm{S}$} & $20 \mathrm{mo}$ & 42 & 1.79 & 35.7 & 50.0 & 14.3 & - & - & - \\
\hline & $10 \mathrm{mo}$ & 91 & 1.26 & 73.6 & 26.4 & - & - & - & - \\
\hline
\end{tabular}

Table 3. Variation of ovulation rate with age and season in D'man ewes (9).

\begin{tabular}{|c|c|c|c|c|c|c|c|c|c|c|c|}
\hline \multirow{2}{*}{$\begin{array}{l}\text { Age at } \\
\text { joining }\end{array}$} & \multirow[t]{2}{*}{ Season } & \multicolumn{2}{|c|}{ Number of $Q$} & \multirow{2}{*}{$\begin{array}{c}\text { Mean } \\
\text { number } \\
\text { of C.L }\end{array}$} & \multicolumn{7}{|c|}{ Number of $९$} \\
\hline & & endo & with C.L & & 1 & 2 & 3 & 4 & 5 & 6 & 7 \\
\hline \multirow[t]{4}{*}{ Adult } & Nov-Dec & 38 & 34 & 2.82 & 4 & 9 & 11 & 9 & 1 & - & - \\
\hline & May_Jun & 36 & 32 & 3.81 & - & 5 & 8 & 13 & 2 & 2 & 2 \\
\hline & March & 41 & 39 & 2.97 & 4 & 9 & 15 & 7 & 3 & 1 & - \\
\hline & & 115 & 105 & 3.18 & 8 & 23 & 34 & 29 & 6 & 3 & 2 \\
\hline $\begin{array}{l}21-22 \\
\text { months }\end{array}$ & May_Jun & 16 & 15 & 3.40 & 1 & 4 & 3 & 3 & 3 & 1 & - \\
\hline 11 & Nov-Dec & 14 & 11 & 2.27 & 2 & 5 & 3 & 1 & - & - & - \\
\hline months & March & 29 & 25 & 1.92 & 8 & 12 & 4 & 1 & - & - & - \\
\hline
\end{tabular}

Table 4. Least squares means and distribution of ovulation type by breed group.

\begin{tabular}{|c|c|c|c|c|c|c|c|c|c|c|c|}
\hline \multirow{2}{*}{$\begin{array}{l}\text { Breed } \\
\text { Group }\end{array}$} & \multirow{2}{*}{$\begin{array}{c}\text { Number } \\
\text { of } \\
\text { obs. }\end{array}$} & \multirow{2}{*}{$\begin{array}{c}\text { Least } \\
\text { squares } \\
\text { means }\end{array}$} & \multirow{2}{*}{$\begin{array}{l}\text { Stan- } \\
\text { dard } \\
\text { error }\end{array}$} & \multicolumn{8}{|c|}{ Frequency $(\%)$} \\
\hline & & & & 1 & 2 & 3 & 4 & 5 & 6 & 7 & 8 \\
\hline D'man & 179 & 2.56 & .07 & 14.7 & 32.9 & 27.1 & 17.1 & 5.0 & 2.1 & 1.3 & .4 \\
\hline Sardi & 411 & 1.23 & .05 & 74.2 & 25.5 & .3 & - & - & - & - & - \\
\hline $\mathrm{D} \times \mathrm{S}$ & 191 & 1.92 & .09 & 45.1 & 40.7 & 12.8 & .8 & - & - & - & - \\
\hline
\end{tabular}


Table 5. Embryo survival in D'man dy number of ovulations.

\begin{tabular}{lcccccc}
\hline & \multicolumn{4}{c}{ Ovulation rate } & Authors \\
\cline { 2 - 5 } & 1 & 2 & 3 & 4 & $5,6,7$ & \\
\hline Embryo & & 90 & 82 & 69 & 58 & $(9)$ \\
Survival & & 90 & 78 & 71 & 49 & $(20)$ \\
$(\%)$ & 88 & 87 & 79 & 67 & & $(5)$ \\
\hline
\end{tabular}

Hanrahan (15) was derived for all ewes which ovulated:

$$
\mathrm{Y}=1.198 \mathrm{X}-.116 \mathrm{X}^{2}
$$

where $\mathrm{X}$ and $\mathrm{Y}$ indicate $\mathrm{OR}$ and LS respectively. This equation shows that the highest LS of 2.65 corresponds to an OR of 4.78. ES of crossbred ewes was better than the average of parental breeds; heterosis was $14.6 \%$. This result shows that ES is a heterotic trait.

\section{Endocrine mechanism of multiovulation}

Comparative studies on folliculogenesis in $\mathrm{D}$ and Timahdite around birth and in the adult indicate that $\mathrm{D}$ has more large follicles and less atretic follicles which is mainly due to high level of FSH $(19,21)$. In recent studies, D senstivity to estrogen negative feed-back and to gonadotrophins was tested.

Results summarized in table 6 and table 7 indicates that the D had a greater OR after PMSG than did the non-prolific breeds either in adult and ewe-lambs. This is in agreement with results of other experiments $(3,11)$ showing greater gonadotrophin responsiveness in animals with higher natural OR. However, when the response to PMSG is expressed as a multiple natural OR, the non-prolific breed seems to be more responsive than the $\mathrm{D}$. The relative increase in OR when the dose of PMSG increased from 250 to 500 was $43 \%$ and $92 \%$ for D and T ewes, respectively (31).

On the other hand, estrogen negative feedback is more marked in $\mathrm{T}$ than in D ewes. This was shown in ovariectomized ewes fitted with estrogen implants. In these animals, the levels of FSH and LH were singificantly higher in D than in T (LAHLOU-KASSI, unpubl. data). It was concluded that $\mathrm{D}$ ewes are less sensitive to estrogen feedback mechanism.

Multiovulation seems to be a resultant from higher level of FSH allowing growth of more follicles that are in last stages of development and a higher sensitivity of follicles to gonadotrophins probably due to higher concentration of $\mathrm{FSH}$ and $\mathrm{LH}$ receptors. This hypothesis is under investigation (LAHLOUKASsI, unpubl. data).

\section{Photoperiod effect on breeding season in D'man}

\subsection{In the female}

Total seasonal anestrus is absent in this breed, even in ewes out of their natural in-

Table 6. Induced ovulation rate by using PMSG and HCG in D'man and Sardi ewe-lambs. (Lahlou-Kassi et al., unpubl. data).

\begin{tabular}{|c|c|c|c|c|c|c|c|c|c|c|c|c|c|c|c|}
\hline \multirow[t]{2}{*}{ Group } & \multirow[t]{2}{*}{$\mathrm{n}$} & \multirow{2}{*}{$\begin{array}{c}\text { Age } \\
\text { (days) }\end{array}$} & \multirow{2}{*}{$\begin{array}{c}\text { Weight } \\
\text { (kg) }\end{array}$} & \multirow{2}{*}{ 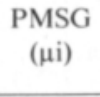 } & \multirow{2}{*}{$\begin{array}{c}\text { HCG } \\
(\mu \mathrm{i})\end{array}$} & \multicolumn{10}{|c|}{ Number of C.L } \\
\hline & & & & & & 1 & 2 & 3 & 45 & 6 & 7 & 8 & 9 & 10 & 11 \\
\hline D'man & 7 & $95.4 \pm 11.9$ & $9.7 \pm 2.1$ & 400 & 500 & 1 & 3 & - & $\frac{1}{(7} 4$ & $\overline{14 \pm}$ & $\begin{array}{c}1 \\
3.36)\end{array}$ & - & - & - & 1 \\
\hline D'man & 7 & $96.6 \pm 7.6$ & $11.4 \pm 3.9$ & 200 & 500 & 1 & 1 & 2 & $-_{(4}-\frac{}{2}$ & $\frac{-}{25 \pm}$ & $\overline{0.83)}$ & - & - & - & - \\
\hline D'man & 6 & $87.5 \pm 11.6$ & $9.8 \pm 1.9$ & - & 500 & - & 1 & 1 & ${ }^{-}-{ }^{2} \quad 2$ & $.5 \pm$ & $\overline{0.5}$ & ) & - & - & 一 \\
\hline Sardi & 7 & $103.1 \pm 4.9$ & $13.0 \pm 3.4$ & 400 & 500 & 3 & 1 & 1 & $-_{(5}-$ & $6 \pm$ & $-\overline{0.8}$ & ) & - & - & 一 \\
\hline Sardi & 7 & $97.8 \pm 6.2$ & $12.8 \pm 2.4$ & 200 & 500 & 2 & 1 & - & $-_{(3}-$ & $\overline{33 \pm}$ & $-\overline{0.47}$ & - & - & - & - \\
\hline
\end{tabular}



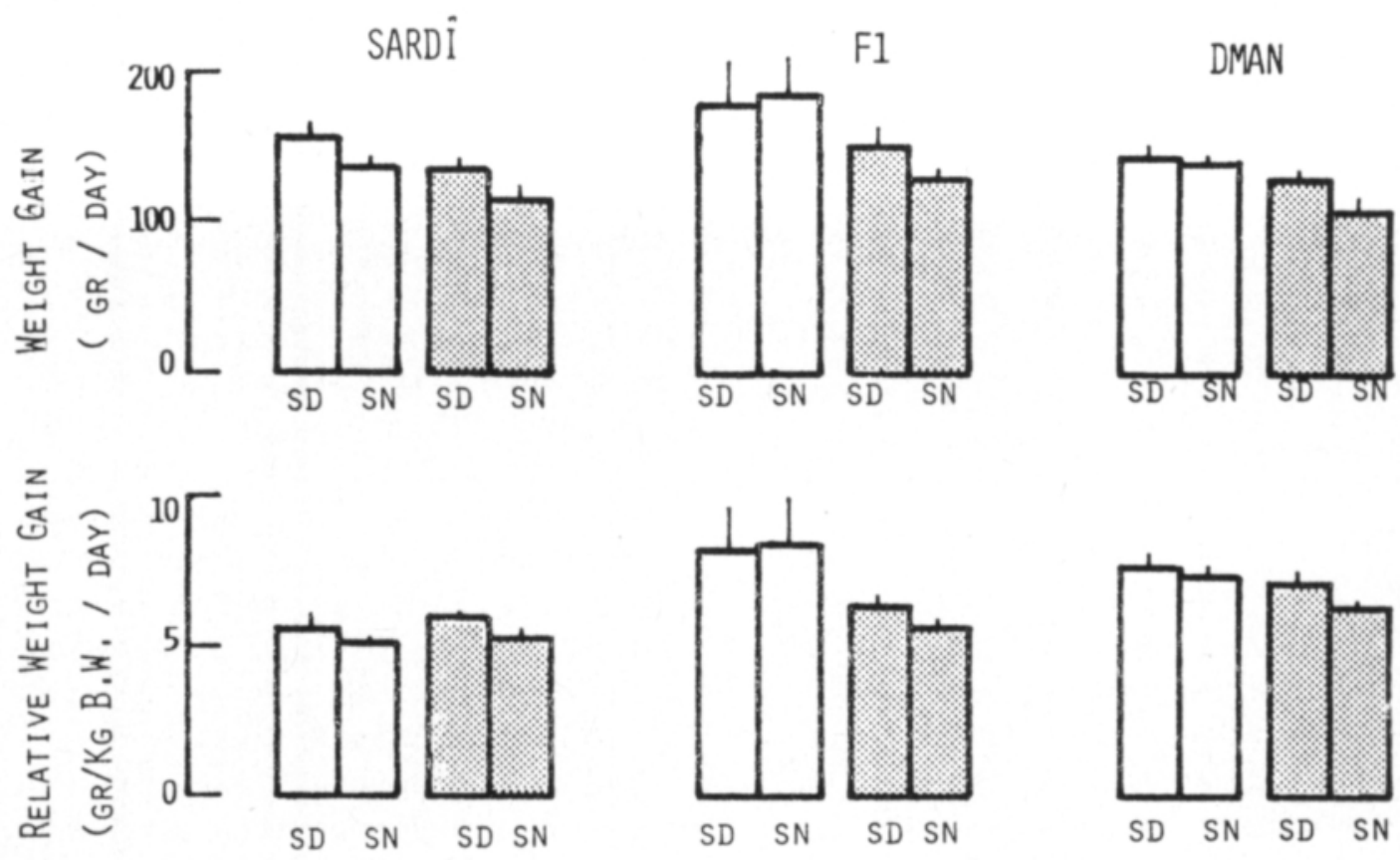

WiNTER

SUMMER

Fig. 1. Weight gain per animal and per $\mathrm{Kg}$ of body weight in genotypes $\mathrm{S}, \mathrm{S} \times \mathrm{D}$, and $\mathrm{D}$ placed in shade (SH) or exposed to the sun (SN) during winter and during summer.

habitat. Maximum estrus activity occurs around summer and winter solstices, and a minimum activity occurs in October and around March. However, the percentage of ewes in estrus is never lower than $50 \%(7,17)$. These results suggest that $\mathrm{D}$ breed is less sensitive to photoperiod. This hypothesis was tested on $20 \mathrm{D}$ maintained under an artificial photoperiod corresponding to that of Lat :

Table 7. Ovulation rate after treatment with different doses of PMSG.

\begin{tabular}{cccc}
\hline \multirow{2}{*}{$\begin{array}{l}\text { Dose } \\
\text { of PMSG }\end{array}$} & \multicolumn{2}{c}{ Ovulation rate } & \multirow{2}{*}{ Authors } \\
\cline { 2 - 3 } & \multicolumn{1}{c}{ D'man } & Timahdite & \\
\hline 0 & $1.56 \pm 0.2$ & $1.02 \pm 0.0$ & $(27)$ \\
250 & $2.90 \pm 1.26$ & $1.36 \pm 0.75$ & $(32)$ \\
375 & $2.40 \pm 0.4$ & $1.57 \pm 0.2$ & $(27)$ \\
400 & $3.03 \pm 1.88$ & & $(24)$ \\
500 & $4.16 \pm 1.95$ & $2.62 \pm 1.57$ & $(32)$ \\
750 & $6.72 \pm 1.2$ & $4.58 \pm 1.1$ & $(27)$ \\
1500 & $11.01 \pm 1.3$ & $6.93 \pm 1.0$ & $(27)$ \\
\hline
\end{tabular}

$56^{\circ} \mathrm{N}$ (Edinburgh, Scotland). Estrus and ovarian activity of these ewes was compared to a control group (Lat : $32^{\circ} \mathrm{N}$, Tadla, Morocco). Results of this experiment (Table 8) show that estrous behaviour was affected by Scottish photoperiod in D. Number of ewes showing estrus was low during the Sept-Dec period in the first year of the experiment and between July and Dec in the second year. This was not clearly shown in S ewes of which breeding season is centered around the winter solstice. However, ovarian activity determined by plasma progesterone levels was not affected in D (18). This pleads in favour of a lower sensitivity of this breed to photoperiod variation.

\subsection{In the male}

In the male, a study on characteristics of semen from 5 rams collected by artificial vagina weekly for 2 years showed that volume, gross motility and individual motility were 


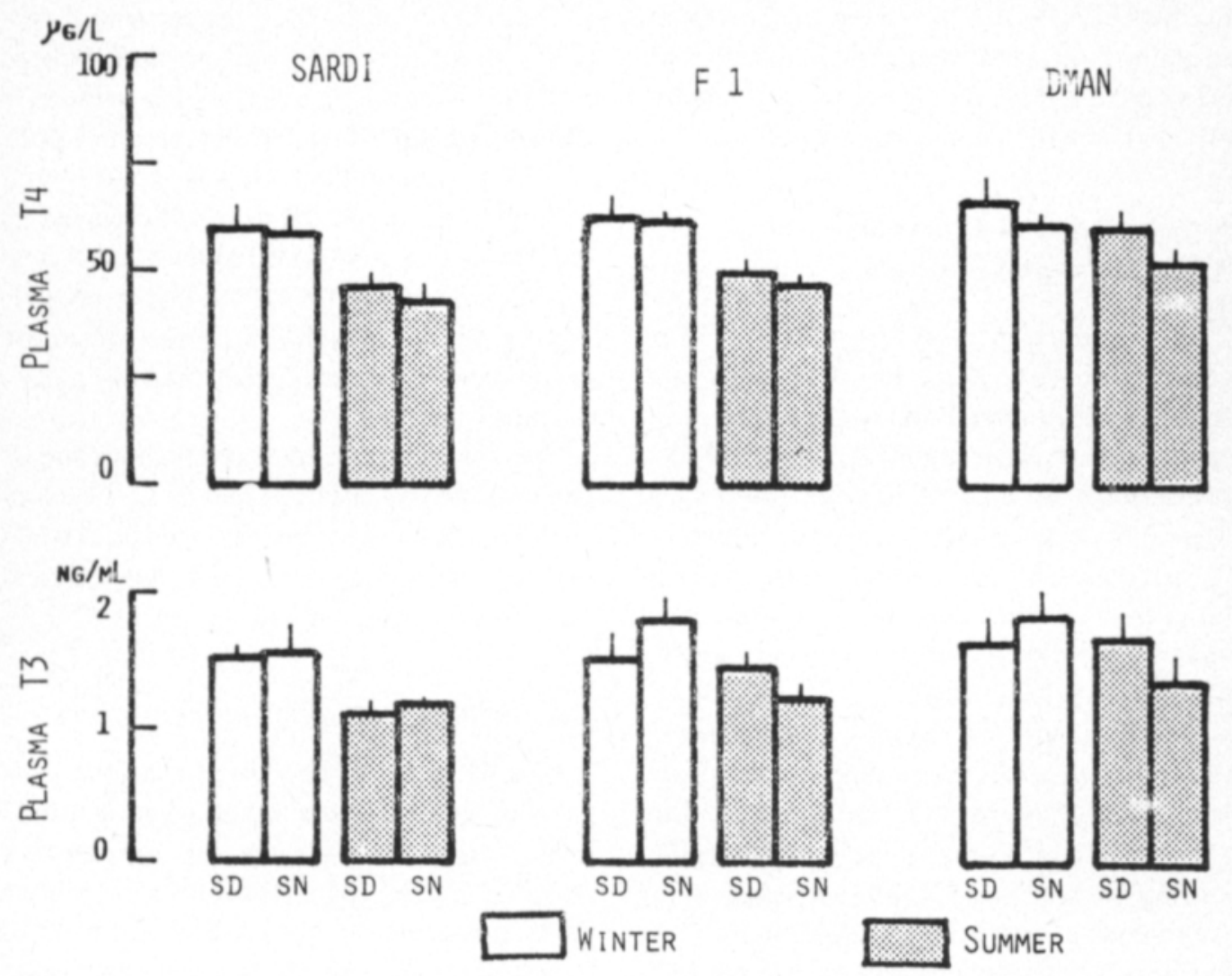

Fig. 2. Plasma thyroxine (T4) and triodothyronon (T3) in genotypes $\mathrm{S}, \mathrm{S} \times \mathrm{D}$, and $\mathrm{D}$ placed in shade (SH) or exposed to the sun $(\mathrm{SN})$ during winter and during summer.

relatively constant. However, concentration was affected by season and decreased between May and August, may be due to poor nutritional level. The D ram seems to reach exhaus- tion earlier than $\mathrm{S}$ rams as concentration of semen decreased rapidly by rank of ejaculate (32).

The libido in D ram seems to be higher than

Table 8. Ovarian activity of D'man and Sardi ewes as monitored by changes in plasma progesterone level and by detection of oestrus under two photoperiods during a period of 682 days.

\begin{tabular}{|c|c|c|c|c|}
\hline Group & $\begin{array}{c}\text { Theoretical } \\
\text { no. of } \\
\text { ovul. or est. }\end{array}$ & $\begin{array}{c}\text { Observed } \\
\text { no. of } \\
\text { ovul. }\end{array}$ & $\begin{array}{c}\text { Observed } \\
\text { no. of } \\
\text { estrus. }\end{array}$ & $\begin{array}{c}\text { Mean } \\
\text { efficiency } \\
\text { of est. exp }\end{array}$ \\
\hline \multicolumn{5}{|l|}{ D'man. } \\
\hline Control & 351 & $\begin{array}{c}314 \\
34.8 \pm 3.9\end{array}$ & $\begin{array}{c}211 \\
23.4 \pm 4.2\end{array}$ & $67.2 \%$ \\
\hline Experimental & 779 & $\begin{array}{c}736 \\
36.8 \pm 1.9 \mathrm{~ns}\end{array}$ & $\begin{array}{c}345 \\
17.3 \pm 5.9^{* * *}\end{array}$ & $46.9 \%$ \\
\hline Control & 442 & $\begin{array}{c}271 \\
22.5 \pm 3.5\end{array}$ & $\begin{array}{c}230 \\
19.2 \pm 4.2\end{array}$ & $84.5 \%$ \\
\hline Experimental & 664 & $\begin{array}{c}418 \\
23.3 \pm 3.6 n s\end{array}$ & $\begin{array}{c}287 \\
15.3 \pm 6.3^{*}\end{array}$ & $68.7 \%$ \\
\hline
\end{tabular}


in other breeds. In Tadla experimental farm, breeding record indicates a possible high male effect of ram from this breed, but this hypothesis was not thoroughly investigated.

\section{Adaptation of D'man sheep to environmental constraints}

The production of sheep is influenced by genetic potential of the breed (growth rate, fertility) and its adaptation to the environmental stress (heat, solar radiation, water and food restriction). Because of its high prolificacy, there is a rising interest to use the D outside its original habitat either as a pure breed or more than often in cross breeding. The most advanced program is the crossbreeding with the $\mathrm{S}$ in the Tadla region.

The D is originally reared in the shade of the oasis where it is watered permanently and fed with a high nitrogen ration composed with alfa-alfa. The $\mathrm{S}$ is grazing in the Tadla region. During the hot season, this breed is fed on the stubble which are poor in nitrogen and high in fiber. In addition, it is exposed to solar radiation and subjected to unfrequent watering. The production under this environment depends on the ability of the animals to economize water and nitrogen and to minimize the effect of heat stress. Comparative studies have been made on water turnover, urea recycling and reactions to heat stress in Sardi, D'man and F1.

\subsection{Water turnover and urea recycling}

Water turnover which expresses the water needs was measured during the critical phases of the production cycle such as pregnancy, lactation, and the growth period using tritium as tracer. Table 9 shows that water turnover under thermoneutral conditions is higher in $\mathrm{S}$ than in D and F1. These differences were significant during pregnancy and growth.

In ruminants, it is well established that endogenously produced urea is partly degraded to ammonia in the digestive tract and partly excreted in the urine. The ammonia produced in the rumen can be used for microbial protein synthesis (14). The proportion of urea degraded in the digestive tract (= urea recycling) increases when the diet becomes poor in nitrogen. In addition, it was reported that the ability to recycle the urea is influenced by the genotype (25). When fed with a low protein diet, $\mathrm{S}$ and the $\mathrm{F} 1$ show a higher urea recycling rate than D and this effect was more pronounced during pregnancy than during lactation (Table 9).

The low water turnover and high urea recycling rate seen in $\mathrm{S}$ can be related to the adaptation to the stress of low nitrogen intake and unfrequent drinking observed during the summer in the Tadla region.

\subsection{Seasonal heat stress and growth}

Berger et al. (2) reported that the post weaning growth is depressed when it occurs during the summer period. To elucidate this seasonal difference in growth, a comparative study was conducted in growing lambs ( 3 to 6 months age) during the summer and during the winter with a similar nutrition level. The animals from 3 genotypes (D, S and F1) were divided in 2 groups, one exposed to the sun and the other having access to the shade. The results in the Table 10 confirm that the post weaning growth is depressed in the summer, but mainly when the animals are exposed to the sun. This effect was not caused by a decrease in food intake, but by a decrease in food conversion efficiency.

When growth was compared in the 3 genotypes, S and F1 showed the highest absolute growth in comparison with S. Since the 3 genotypes do not have the same mature weight, the relative growth rate was used to compare the 3 breeds. It appeared that the D and the F1 have a much higher $(28 \%)$ relative growth rate as compared to the $\mathrm{S}$. In addition, the relative growth rate was depressed during summer in D and F1 but not in the S.

It is known that the level of thyroid hormones are influenced by ambient temperature and genetic background and that there is a 
Table 9. Water turnover and urea recycling rate in D'man, Sardi and F1 during pregnancy, lactation and growth.

\begin{tabular}{|c|c|c|c|c|}
\hline & \multicolumn{2}{|c|}{ Water turnover } & \multicolumn{2}{|c|}{ Urea recycling } \\
\hline & $T_{1 / 2}$ (h) & $\left(\mathrm{ml} / \mathrm{kg}^{75} / \mathrm{d}\right)$ & $(\mathrm{mmol} / \mathrm{kg} .75 / \mathrm{d})$ & $\%$ \\
\hline \multicolumn{5}{|l|}{ Pregnancy } \\
\hline D'man & $131 \pm 3$ & $228 \pm 8$ & $5.7 \pm 0.9$ & $71 \pm 2$ \\
\hline Sardi & $217 \pm 15$ & $161 \pm 17$ & $9.4 \pm 0.7$ & $80 \pm 4$ \\
\hline$F_{1}$ & $153 \pm 8$ & $201 \pm 10$ & $8.3 \pm 1.2$ & $76 \pm 3$ \\
\hline \multicolumn{5}{|l|}{ Lactation } \\
\hline D'man & $98 \pm 7$ & $306 \pm 14$ & $5.0 \pm 0.4$ & $74 \pm 4$ \\
\hline Sardi & $115 \pm 6$ & $285 \pm 15$ & $5.5 \pm 1.3$ & $77 \pm 4$ \\
\hline$F_{1}$ & $101 \pm 7$ & $307 \pm 17$ & $6.1 \pm 1.1$ & $76 \pm 4$ \\
\hline \multicolumn{5}{|l|}{ Growth } \\
\hline D'man & $103 \pm 3$ & $260 \pm 10$ & - & - \\
\hline Sardi & $127 \pm 5$ & $229 \pm 13$ & - & - \\
\hline$F_{1}$ & $106 \pm 3$ & $279 \pm 10$ & - & - \\
\hline
\end{tabular}

Table 10. Absolute growth rate and food efficiency coefficient during the winter and during the summer in lambs ( 3 to 6 months age). The animals were divided in 2 groups, one exposed to the sun and the other having access to the shade.

\begin{tabular}{|c|c|c|c|c|}
\hline & \multicolumn{2}{|c|}{ Winter } & \multicolumn{2}{|c|}{ Summer } \\
\hline & Shade & Sun & Shade & Sun \\
\hline Growth (g/day) & $160 \pm 11$ & $154 \pm 10$ & $139 \pm 6$ & $118 \pm 9$ \\
\hline $\begin{array}{l}\text { Food efficiency } \\
\text { (Mcal ME/kg gain) }\end{array}$ & 13.7 & 14.0 & 16.0 & 18.7 \\
\hline
\end{tabular}

relationship between thyroid activity and growth rate $(1,13)$. A related question is the possible role that thyroid function (known to be depressed by environmental heat) played in the observed reduced growth rate during the summer and in the difference in growth between breeds. In fact, it has been shown in this study that thyroxine (T4) and triiodothyronin (T3) were depressed during summer in all the 3 genotypes. On the other hand, the D showed higher levels of $T_{4}$ and $T_{3}$ than $S$ with intermediate levels for the $F_{1}$.

\section{Conclusion}

Results obtained by different authors suggest that prolificacy in D may be related to other parameters (low age at puberty, non seasonality, ...). All these components of reproductive efficiency may have the same basic mechanism. The low sensitivity of pro- lific breeds to estrogen negative feed-back (22) and the role of this feed-back in seasonality (23) may explain the relationship between reproductive parameters.

Results from the study on genetic support of prolificacy in D shows that the presence of a major gene controlling this trait is controversial. The existence of this type of gene will allow a selection for two strains, one with a LS $\leq 2$ and one with a LS $\geq 3$. This selection offers possibility of controlling LS and use of D by farmers for cross-breeding with non-prolific ewes according to their goals and their specific production system.

D shows, in addition to its high prolificacy, a high potential for fast growth which can be efficiently used in cross-breeding. This characteristic is associated with high water turnover and high levels of blood thyroid hormones. However, D appears to be more suceptible to the effect of environmental stress of the summer period than the $\mathrm{S}$. 
Aknowledgements: The authors would like to record their appreciation of the support provided for this work by the Title XII Small Ruminant CRSP, Grant No. AID/
DSAN/XII/G-0049, by the IAEA, Projects MOR/5/015 and $3159 /$ IG and by IFS grant B/464.

\section{References}

1. Baccari, F., Johnson, H.D. \& Lerory Hann, G. 1983. Proc. Soc. Experim. Biol. Med. 173, 312.

2. Berger, Y.M., Bradford, G.E., Essaadi, A., JohnSon, D.W., Bourfia, M. \& Lahlou-Kassi, A. 1988. Performance of D'man and Sardi breeds of sheep in purebred and crossbred matings on an accelerated lambing schedule. III. Lamb mortality, growth and production per ewe. Submitted to Small Ruminant Research.

3. Bindon, B.M., Thimonier, J. \& Piper, L.R. 1978. Timing of pré-ovulatory LH discharge in high fecundity sheep. Proc. Aust. Soc. Reprod. Biol., 10, 82 (Abstr.).

4. Bouix, J., Kadiri, M. \& Chari, A. 1974. Performances enregistrées dans les troupeaux pepinières de la race D'man. Al Awamia, 52, 67-97.

5. Boujenane, I., Chafik, A., Bradford, G.E. \& BerGER, Y.M. 1988. Taille de la portée et ses composantes chez la brebis D'man, Sardi et D'man $\times$ Sardi. 18èmes journées de l'Ass. Nat. Prod. Anim., 10-11 Mars 1988, Rabat, Maroc.

6. Boujenane, I., Khallouk, M. \& Kerfal, M. 1988 b. Parametres génétiques des performances de reproduction des brebis de race D'man. Proc. 3rd World Congr. Sheep and Beef Cattle Breed. 2: 653 -656 .

7. BоuкнцıQ, R. 1986. Variations saisonnières de l'âge à la puberté, de la cyclicité sexuelle et de l'anoestrus post-partum chez des femelles de race D'man, Sardi et leur produits de croisement. Thèse Doct. Vét. IAV Hassan II, Rabat, Maroc.

8. Boutgayout, M. 1980. Bilan de reproduction et contrôle de croissance de deux troupeaux ovins D'man et Sardi. Thèse Doct. Vet. IAV Hassan II, pp 6, 8, 50, 109.

9. Bradford, G.E., Lahlou-Kassi, A., Berger, Y.M., Boujenane, I. \& Derqaoui, L. 1988. Performance of D'Man and Sardi breeds of sheep in purebred and crossbred matings on an accelerated schedule. II. Ovulation rate and embryo survival. Submitted to Small Rumin. Res.

10. Bradford, G.E., Quirke, J.F. \& Famula, T.R. 1986. Fertility, embryo survival and litter size in lines of Targhee sheep selected for weaning weight or litter size. J. Anim. Sci. 62: 895-904.

11. Bradford, G.E., Quirke, J.F. \& Hart, R. 1971. Natural and induced ovulation rate of Finnish Landrace and other breeds of sheep. Anim. Prod., 13: $627-635$.
12. Bradford, G.E., Quirke, J.F., Sitorus, P., Inounu, I., Tiesnamurti, B., Bell, F.L., Fletcher, I.C. \& TORELl, D.T. 1986. Reproduction in Javanese sheep: Evidence for a gene with large effect on ovulation rate and litter size. J. Anim. Sci. 63: 418-431.

13. Draper, S.A., Hayens, N.B., Falconer, I.R. \& Lamming, G.E. 1966. Anim. Prod. II: 399.

14. Egan, A.R., Boda, K. \& Varady, J. 1986. In control of Digestion and Metabolism in Ruminants, edited by Milligan, Grovum and Dobson. Prentice Hall, Englewood Cliffs, NJ.

15. Hanrahan, J.P. 1982. Selection for increased ovulation rate, litter size and embryo survival. Proc. 2nd World Congr. Genet. Appl. Livest. Prod. 5: 294 -309 .

16. Jorıo, A. 1987. Dynamique folliculaire comparée pendant la période pré-pubère chez deux races de bredis different par leur taux d'ovulation: la D'man et la Timanhite. Thèse de Doct, Université Paris 6, pp 5 117-121.

17. Lahlou-Kassi, A. 1982. Etude comperée de la dynamique folliculaire cyclique des brebis à haut et à bas taux d'ovulation: Races D'man et Timahdite. Thèse Doct. Es-Sciences., IAV Hassan II, Rabat, Maroc.

18. Lahlou-Kassi, A. \& BoukhliQ, R. 1987. Oestrus behaviour and ovarian activity in D'Man and Sardi breeds of Moroccoan sheep under normal and experimental photoperiod. Proc. Final Res. Coord. Meet. (IAEA), Rabat, March, 1987: 131-139.

19. Lahlou-Kassi, A. \& MarlanA, J.C. 1984. Ovarian follicular growth during the oestrous cycle in two breeds of ewes of different ovulation rate, the D'man and the Timahdite. J. Reprod. Fert., 72: 301-310.

20. Lahlou-Kassi, A. \& Marie, M. 1985. Sexual and ovarian function of the D'man ewe. In Genetics of Reproduction in Sheep (eds Land, R.B. and Robinson, D.W.), Butterworths, London: 245-260.

21. Lahlou-Kassi, A., Schams, D. \& Glatzel, P. 1983. Plasma gonadotrophin concentrations during the oestrous cycle and after ovariectomy in two breeds of sheep with low and high fecundity. J. Reprod. Fert., 70: 165-173.

22. Land, R.B., Pelletier, J., Thimonier, J \& Mauléon, P. 1973. A quantitative study of genetic differences in the incidence of oestrus, ovulation and plasma luteinizing hormone concentration in the sheep. J. Endocr., 58: 305-317.

23. Legan, S.J., Karsh, F.J. \& Foster, D.L. 1977. The 
endocrine control of seasonal reproduction in the ewe: A marked change in response to the negative feed back of Estradiol on Luteinizing Hormone. J. Endocr., 101, 3: 818-824.

24. Manar, S. 1987. Etude des facteurs influençant la synchronisation des chaleurs et l'insémination artificielle chez les ovins. Thèse Doct. Vét. IAV Hassan II, 83.

25. Moussa, H.M., Alı, K.E. \& Hume, I.D. 1983. Comparative Biochemistry and Physiology, 74A: 715.

26. PiPer, L.R. \& Bindon, B.M. 1985. The single gene inheritance of the high litter size of the Boorola Merino. In Genetics of Reproduction in Sheep. Eds. Land, R.B. and Robinson, D.W.), Butterworths, London: 115-125.

27. Quirke, J.F., Meyer, H.H., Lahlou-Kassi, A., HanRahan, J.P., Bradford, G.E. \& Stabenfeldt, G.H. 1987. Natural and induced ovulation rate in prolific breeds of sheep in Ireland, Morocco and New Zealand. J. Reprod. Fert. B1: 309-316.

28. Ricordeau, G., Razungles, J., Eychenne, F. \& Tсhamitchian, L. 1976. Performances de reproduction des brebis Berrichon du Cher, Romanov et croisées. II. Composantes de la prolificité. Annal. Génét. Sel. Anim, 8: 25-35.
29. Ricordeau, G., Tchamitchian, C., Lefevre, J.C., Brunel, J.C. \& Desvignes, A. 1976. Amélioration de la productivité des bredis Berrichon du Cher par croisement. III. Performances de reproduction des trois premières générations de croisés entre les races Berrichon du Cher et Romanov. Annal. Génét. Sel. Anim., 8: 405-419.

30. Scaramuzzi, R.J. \& Radford, H.M. 1983. Factors regulating ovulation rate in the ewe. J. Reprod. Fert., 30: 395-405.

31. Tibary, A., Boukhuq, R., Adnani, M. \& Tó, F. 1988. Importance de l'examen du bélier en gestion de la reproduction ovine: Variations saisonnières de la qualité du sperme et dominantes pathologiques. 18èmes journées de l'Association Nationale Ovine et Caprine, 10-11 Mars 1988, Rabat, Maroc.

32. Tibary, A., Manar, S., Boukhliq, R. \& Adnani, M. 1988. Factors affecting estrus synchronization in two Moroccan breeds of sheep (Timahdite and D'man). Submitted to the 11th Congr. on Anim. Reprod. A.I., 1988, Dublin, Ireland.

33. Wheeler, A.G. \& LAND, R.B. 1977. Seasonal variation in oestrus and ovarian activity of Finnish Landrace, Tasmanian, Merino and Scottish Blackface. Anim. Prod., 24: 363-376. 